\title{
The Identification and Comparison of the Requirements Placed on Product Managers during the Recruitment Process
}

\author{
- Wroblowská Zuzana, Ruda Tomás
}

\begin{abstract}
The submitted paper focuses on personality traits and behavioural competencies of a key role bearer in product oriented marketing management, generally referred to as product management. An interdisciplinary approach was applied while looking into this subject, since both research into theoretical bases and analysis of the current state of the topic and the tendencies of its development required work in several fields of study. Based on research in the field of secondary data, the assumption was set that a product manager is an example of a knowledge worker of the 21 st century and that the business practice sees him/her as such, which has an effect on the requirements a candidate for this position is confronted with in the recruitment process. An independent research project was carried out and it confirmed that product managers are considered to be knowledge workers and that independence and analytical thinking skills were among the most common requirements for product managers both in 2007 and 2014. A comparison of results from 2007 and 2014 also showed some differences. The statistical verification confirmed a shift in requirements within the interpersonal competency group. The findings were used to formulate recommendations for the recruitment strategy and realization of selection for positions in product management.
\end{abstract}

Keywords: knowledge worker, personality traits, product management, product manager, requirements, recruitment strategy, skills

JEL Classification: D83, M12, M31, M51

\section{INTRODUCTION}

Constant increasing of competitive ability and the related need to find critical competencies, which determine a company's standing on the market, is a major challenge for businesses of all sizes and fields of expertise. Economic power is not enough; in order to survive, organizations must show that they are prepared to react to changes in their environment and potentially also initiate these changes. It is innovation that determines success and the future. There is high rate of agreement amongst experts that in the creation of competitive advantage, human capital is the crucial component of intangible assets, because people's specific traits make them the most dynamic and most flexible factor.

Human resources are at the centre of this paper's research interest. It is specifically focused on the human factor in product management, because products and particularly product innovations have been a matter of interest for businesspeople for decades. In the present, markets for products and services are dynamically changing and it can be assumed that the human factor in 
product management, which is approached as an interdisciplinary business function in this paper, reflects these changes. In order for a bearer of the product management key role of product manager to succeed in an environment formed by deregulation, technologies, information networks, globalization, consumer participation based on awareness and the ability of consumers to spread their voice, tough competition and other external forces (Kotler \& Keller, 2012), they have to have both knowledge and personality prerequisites.

We deem it useful to focus on requirements on product managers also because it is a subject relevant for both sides of the labour market; for candidates for this job and for employers looking for the most capable candidate who is most suitable for the given company. With regard to this aspect, job advertisements were chosen as the source of primary data and using the method of content analysis in a form first published by Wroblowská (2011) the findings regarding the present state of requirements were joined with a comparison with a set of psychological requirement applied to product managers in the Czech Republic in the period of economic boom right before the beginning of the economic crisis in the USA, which had a severe impact on markets of both products and services, as well as labour market in the European Union, which includes the subject market as an integral part. The results of this research project are followed by recommendations for strategy and realization of recruitment and selection of product managers, which are based on a timeless theoretical framework of knowledge management.

\section{THEORETICAL BACKGROUND, STATE OF THE SUBJECT MATTER, TENDENCIES OF ITS DEVELOPMENT}

Because of the subject, the work with secondary data required an interdisciplinary approach; therefore, theoretical findings essential for this paper will be introduced in independent subchapters.

\subsection{Marketing Management and Product Management}

Marketing, which was for years advertised as the concept that companies must be customerand-market driven, is now, because of the social transformations, defined as "the activity, set of institutions, and processes for creating, communicating, delivering, and exchanging offerings that have value for customers, clients, partners, and society at large" (Kotler \& Keller, 2012), and as the authors state, that requires a large amount of work and skills. Assuming that at least one side is striving to satisfy the other's needs, marketing management, according to Kotler and Keller (2012), can be approached as "the art and science of choosing target markets and getting, keeping, and growing customers through creating, delivering, and communicating superior customer value." From the point of view of company management, marketing can be seen as a management process which uses the resources of the whole company in order to satisfy the needs of selected groups of customers in order to reach the goals of both sides (McDonald \& Wilson, 2012).

In company organization, marketing specialists usually have the role of an intermediary, with the task to understand the customers' needs and spread their voice into other functional departments of the organization. Marketing departments can be organized in several different ways, 
with the functional organization being less effective the higher the number of products and markets becomes (Webster, 2002 in Kotler \& Keller, 2007). The future of creative marketing organization, according to Kotler and Keller (2012), lies in focusing on and organizing primarily around customer markets and segments.

Product management is a part of the marketing management process. Tomek and Vávrová (2009) emphasize that product management means an integrated process of product development and creation, which corresponds to the market's needs, and at the same time they admit that practical realization of product management can bring various status for product management and thus also of employees (product managers) carrying out this work.

In businesses with horizontal structure instead of, or complementary to, a vertical structure, analytic, planning, budgetary and realization activities are a responsibility of product managers or brand managers. In principle it is expected that they manage the entrusted part of a product portfolio both on the level of strategy and on a tactical-operative level. Lehmann and Winer (2005) stated that the main task of their role is to make the whole organization support marketing programmes based on a product plan. Participation on the process of new product development is an important part of a product manager's work (Lehmann \& Winer, 2002; Kotler \& Keller, 2012).

Crawford and Di Benedetto (2000) believe that the process of new product development can be organized in several ways, differentiated by the level of projectization. Teams organized on the principle of interfunctional collaboration are responsible for innovation in many fields and experts agree on the increasing significance of this organization form (Kotler \& Keller, 2012; Kumar, 2008; Tomek \& Vávrová, 2011, etc.). In innovative companies, a product manager is most frequently a member or a leader of a cross-functional team. In such companies the case of a product manager's work role is an example of a function oriented towards the beginning of company value chain, which is typical for accepting strategic decisions (Gorchels, 2011).

\subsection{Human Capital and Knowledge Management}

Human capital is seen as one of the two main categories of intellectual capital. The second component, structural capital, can then be divided into organizational capital and customer capital, see Edvinsson and Malone (1997). Intellectual capital is defined as the sum of all knowledge that companies could utilize for competitive advantage (Subramaniam \& Youndt, 2005).

This paper is based on a definition, which broadens and gives accuracy to the original definition of the term "human capital" by Schultz (1981): "Human capital represents the human factor in the organization; the combined intelligence, skills and expertise that gives the organization its distinctive character. The human elements of the organization are those that are capable of learning, changing, innovating and providing the creative thrust which if properly motivated can ensure the long-term survival of the organization.” (Bontis et al., 1999 in Armstrong, 2006)

Human capital and knowledge management have a close relationship, because knowledge is one of the attributes of human capital. In the words of the visionary Peter Drucker, who was the first to ever use the term "knowledge worker", the success rate of institutions will be based on whether they effectively apply the knowledge of knowledge workers. Sveiby (1997) relates the 
two theories of knowledge management to profession groups; in relation to the first he views knowledge management as information management and he connects the second one with seeing knowledge management as people management. The main characteristic of knowledge workers according to Mládková is the fact that their work consists of creating, distributing or applying knowledge. The author defines a knowledge worker as a worker with specific knowledge or a knowledge set, which is important for the company (Mládková, 2004).

Reboul et al.'s list of knowledge worker characteristics inclines towards the approach to knowledge workers as professionals, whose jobs require constant learning and improvement, and they add that the productivity and quality of their work is very difficult to measure, since every knowledge worker works differently and their productivity can be influenced by different factors (Reboul et al., 2006 in Urbancová, 2013).

\subsection{Personal Determinants of Performance and Behavioural Competencies}

Workers' performance is influenced by a number of factors. Aside from external conditions they also include personal determinants, which include a whole range of individual prerequisites a worker can have for a job. Personal determinants in close relation to performance are attributes and dispositions, which determine how workers fulfil given tasks (Štikař et al., 2003). Psychological attributes of a personality are usually called personality traits. There are a number of traits and they are smaller units than competencies. "Personality trait" means personality characteristic of any person, which differentiates them from another person and has the same manifestations in different situations and conditions (Hall, Lindzey, Loehlin a Manosevitz, 1997 in Franková, 2011). The study of personality strives to divide the human mind into stable areas of function. According to Nakonečný (1998), attempts for unification of various factor-analytic models led to reductions to only reliably determined and most significant factors: one of them is the so called Big Five factor structure. Despite this Big Five structure model, the taxonomy of personality traits is still an actual research area.

There are many definitions of competencies. Some of them put more emphasis on attributes, some on behaviour. This paper is based both on Mansfield's interpretation of the term "competency" from 1999, which approaches competencies as "an underlying characteristic of a person" (Mansfield, 1999 in Armstrong, 2006), and on a newer approach to competencies as "definitions of skills and behaviours that organizations expect their staff to practice in their work" (Rankin, 2002 in Armstrong, 2006). Armstrong defines behavioural competencies (2006) as behavioural expectations, i.e. the type of behaviour required to deliver results under such headings as teamwork communication, leadership and decision-making. They are sometimes known as "soft skills".

\subsection{Requirements on Product Managers and Personality Traits of Knowledge Workers}

Tomek and Vávrová (2009) emphasize that product managers meant to secure success for products on industrial markets need to balance functional and behavioural competencies. Lehmann and Winer (2005) accentuate knowledge, skills and experience gained by education and experience and excellent communication skills with demonstrable persuasion abilities. In a time of on- 
going globalization, where work teams are more and more frequently virtual, Crawford and Di Benedetto (2011) underline personality dispositions of product team leaders, which are typical for creative people; self-confidence, based on knowledge and experience, empathy, self-management, and superb interpersonal communication. Personality prerequisites of creative people can be found in the characteristic of knowledge workers. Mládková (2008) calls the most important ones "gold skills" and includes willingness to take responsibility, problem-solving ability, and creativity. In the strict sense of the word, creativity means an ability determining whether an individual is able to develop creative behaviour in an exceptional manner (Guilford, 1971 in Landau, 1971). Independent creative thinking and behaviour of an individual forms the basis of both team and organization based creative and innovative behaviour, creative products and innovations (Franková, 2011).

In the Czech Republic, product manager is not a profession. The Czech Statistical Office only classifies it as an occupation. For the needs of recruitment it is approached as a work role and job offers sometimes accentuate whether it is a senior or a junior position. In case of knowledge workers it is always necessary to approach activities in the process of recruitment and selection as activities of strategic significance, since they mean obtaining sources of intellectual capital, as experts agree (Armstrong 2006; Noe et. al. 2010; etc.)

\section{OBJECTIVES AND METHODOLOGY}

This paper was designed to focus on the field of psychological requirements on product managers. The goal of the paper is to present partial results of independent research and to connect them with a knowledge base regarding knowledge management and the human factor in product management. The following goal of this paper was to provide inspiration to those responsible for professional training of future product manager and to business practice with recommendations for the strategy and realization of processes of recruitment and selection.

An interdisciplinary approach was applied while looking into this subject, since both research into theoretical bases and analysis of the current state of the topic and the tendencies of its development required work in several fields of study. The methods used in the research project were partly empirical (theoretical research) and partly logical, particularly deduction when working with secondary data, analysis and synthesis. In order to meet the research goal a comparative method was also used.

The theoretical background and part of the discussion is based on an analysis of references which included three types of references: scientific and expert monographs and collections available in the university library under the key word product management; reviewed scientific and expert articles accessed from the EBSCO service using key words personality traits, knowledge, product manager and psychological requirements (Web of Science database was prioritized); and finally two articles publicly available on the web.

The goal of the primary survey was to check the situation on the side of job offers for product managers on the researched labour market and to provide answers to the research questions, which arise from the following research assumption. The research project was designed to verify that a product manager is an example of a knowledge worker in the 21 st century and to provide 
proof that the business practice sees him as such. In order to meet this ambition, two research assumptions were formulated:

- The set of requirements for candidates for the job of product manager will confirm that a product manager is one of the workers who have knowledge, skills and personality prerequisites typical for creative individuals.

- After the period of economic recession and despite the oncoming recovery, employers do not concede from their requirements on newly hired workers for the job of product manager.

In order to meet this goal the content analysis method by Bernard Berelson (1952) was used, which made it possible to use the available job advertisements on a career portal Jobs.cz to gather information regarding the requirements and psychological demands requested from candidates for the job of product manager in the Czech Republic. The data collection took place between March and August 2014. A similar approach to data operationalizing as Wroblowská (2011) used in her dissertation was used, which provided an input for result comparison between 2007 and 2014. Data segments were transferred into an electronic form. The work with transferred data was applied to a so called manifest content analysis according to Plichtová (1996 in Miovský, 2006), which only studies the explicit content of the text. To sort psychological requirements and demands for personality disposition of candidates for the job of product manager a classification of psychological characteristics was used, which is recommended by Hroník (2007) and inspired by a classical profesiogram, which also includes sensory and physical requirements.

We compared those categories of requirements that had cumulated frequency in the whole sample over $3 \%$. The statistical verification of results was conducted using test criteria in the chisquared test according to Řezanková (2007).

\section{RESULTS}

This paper presents and discusses data and results, which are directly related to the paper's goal. Full results of the research project, their discussion and possible applications are now being processed and will be published in a monograph in the end of 2015. Partial results related to requirements on knowledge, specialized and strategic skills and transferable, general competencies, were presented to the experts in a paper published in Slovakia, see Wroblowská and Ruda (2015).

\subsection{Secondary Data Applied in the Research Project.}

The discussion regarding the findings will mention available empirical surveys conducted outside of the Czech Republic. When preparing the independent research, no new information from the empirical research was available, which was meant to research the human factor in product management in the Czech Republic, apart from those which were already published and applied, see Wroblowská (2011, 2012),

\subsection{Content Analysis and Comparison of Requirements in Job Advertisements}

The source of data were job advertisements on the most popular career portal in the Czech 
Republic Jobs.cz, which was already verified by Wroblowská (2011) as a suitable means to fulfil the research goal. The sample size in both waves of survey was intentionally set for 100 advertisements for the job called "product manager". If the job had a different name, for example "junior product manager", the advertisement was not included in the sample. Advertisements for jobs called "brand manager" were also excluded from the sample, because it was not clear from their content whether it was meant to be a manager responsible for a product brand or a manager of corporate brand.

The sorted data segments from researched advertisement text are presented in the form of a frequency chart in Table 1, which also serves as a comparative chart, since it provides information about the results of the survey conducted by Wroblowská (2011) between 2006 and 2007.

Without meaning to get ahead of the discussion, it should be added to the overview of results that terms from the field of competencies were sporadic both in 2007 and 2014. With some exception, such as the competency "goal orientation", the advertisers defined psychological requirement using terms regarding psychological dispositions or attributes.

We add to the results in Table 1 that the chart does not include requirements on candidates' character and self-perception, because their relative frequency in the assessed advertisement sample did not reach $3 \%$ in 2007 or 2014.

Comparison of frequencies of requirements, which are in some academic works and especially in human resources practice connected into a group called soft skills, is illustrated in Figure 1.

Table 2 gives an idea of the procedure and result of applying the independence test. The test criterion was Pearson $\chi^{2}$ test. On the significance level of $0.1 \%, 1 \%$ and $5 \%$ it was tested whether the null hypothesis regarding independence of the analysed variable on the sign representing the year of realization of the advertisement content analysis can or cannot be rejected. A statistically significant difference in the distribution of requirements for interpersonal skills and attributes was confirmed for both $\&=0.01$ and $\&=0.05$, as proven by calculations in Table 2 .

Tab. 1 - Comparison of requirements applied on product manager by advertisers in 2007 and 2014. Source: Independent research

\begin{tabular}{|c|c|c|c|c|c|}
\hline \multirow{2}{*}{\multicolumn{2}{|c|}{ Group }} & \multicolumn{2}{|c|}{2014} & \multicolumn{2}{|c|}{2007} \\
\hline & & \multicolumn{2}{|c|}{ Product manager } & \multicolumn{2}{|c|}{ Product manager } \\
\hline \multicolumn{2}{|c|}{ Psychological requirements } & $\begin{array}{l}\text { Abs. } \\
\text { frequency }\end{array}$ & $\begin{array}{l}\text { Relative } \\
\text { frequency }\end{array}$ & $\begin{array}{l}\text { Abs. } \\
\text { frequency }\end{array}$ & $\begin{array}{l}\text { Relative } \\
\text { frequency }\end{array}$ \\
\hline A & no mental demands of work & 6 & $6,0 \%$ & 7 & $7,0 \%$ \\
\hline \multicolumn{6}{|c|}{ performance prerequisites and abilities } \\
\hline & systematic thinking & 4 & $4,0 \%$ & 3 & $3,0 \%$ \\
\hline & reasoning ability & 10 & $10,0 \%$ & 4 & $4,0 \%$ \\
\hline & $\begin{array}{l}\text { independence/able to work } \\
\text { independently }\end{array}$ & 44 & $44,0 \%$ & 30 & $30,0 \%$ \\
\hline & goal orientation & 8 & $8,0 \%$ & 6 & $6,0 \%$ \\
\hline
\end{tabular}




\begin{tabular}{|c|c|c|c|c|c|}
\hline B & $\begin{array}{l}\text { decisiveness/ability to decide } \\
\text { quickly }\end{array}$ & 9 & $9,0 \%$ & 5 & $5,0 \%$ \\
\hline & conceptual thinking & 11 & $11,0 \%$ & 3 & $3,0 \%$ \\
\hline & analytic thinking/abilities & 43 & $43,0 \%$ & 32 & $32,0 \%$ \\
\hline & thoroughness, preciseness & 6 & $6,0 \%$ & 8 & $8,0 \%$ \\
\hline & creativity & 21 & $21,0 \%$ & 23 & $23,0 \%$ \\
\hline \multicolumn{6}{|c|}{ interpersonal abilities and skills } \\
\hline & $\begin{array}{l}\text { organization and coordination } \\
\text { skills }\end{array}$ & 13 & $13,0 \%$ & 27 & $27,0 \%$ \\
\hline & team player/teamwork ability & 18 & $18,0 \%$ & 21 & $21,0 \%$ \\
\hline \multirow[t]{4}{*}{$\mathrm{C}$} & $\begin{array}{l}\text { comm. skills/ability to com- } \\
\text { municate well }\end{array}$ & 65 & $65,0 \%$ & 65 & $65,0 \%$ \\
\hline & $\begin{array}{l}\text { negotiation abilities (ability to } \\
\text { persuade) }\end{array}$ & 32 & $32,0 \%$ & 11 & $11,0 \%$ \\
\hline & presentation skills & 31 & $31,0 \%$ & 33 & $33,0 \%$ \\
\hline & leadership abilities & 10 & $10,0 \%$ & 6 & $6,0 \%$ \\
\hline \multicolumn{6}{|c|}{ traits and skills connected to motivation and self-control } \\
\hline & initiative, proactive & 16 & $16,0 \%$ & 12 & $12,0 \%$ \\
\hline & $\begin{array}{l}\text { purposefulness, ability to } \\
\text { motivate oneself }\end{array}$ & 15 & $15,0 \%$ & 17 & $17,0 \%$ \\
\hline \multirow[t]{2}{*}{$\mathrm{D}$} & able to work enthusiastically & 12 & $12,0 \%$ & 12 & $12,0 \%$ \\
\hline & $\begin{array}{l}\text { willing to learn new things, } \\
\text { work on oneself }\end{array}$ & 12 & $12,0 \%$ & 12 & $12,0 \%$ \\
\hline \multicolumn{6}{|c|}{ vital capacity and temperament } \\
\hline & $\begin{array}{l}\text { dynamic, energetic, vital } \\
\text { personality }\end{array}$ & 3 & $3,0 \%$ & 9 & $9,0 \%$ \\
\hline $\mathrm{E}$ & active & 12 & $12,0 \%$ & 9 & $9,0 \%$ \\
\hline \multicolumn{6}{|c|}{ conscientiousness, adaptation, prioritizing ability } \\
\hline & $\begin{array}{l}\text { multitasking, prioritizing } \\
\text { ability }\end{array}$ & 3 & $3,0 \%$ & 15 & $15,0 \%$ \\
\hline \multirow[t]{3}{*}{$\mathrm{F}$} & flexibility (mostly time-wise) & 21 & $21,0 \%$ & 23 & $23,0 \%$ \\
\hline & responsibility & 17 & $17,0 \%$ & 13 & $13,0 \%$ \\
\hline & reliability & 5 & $5,0 \%$ & 1 & $1,0 \%$ \\
\hline
\end{tabular}

Table 2 is processed for a group of interpersonal skills and competencies, which are in Table 1 under C.

Figure 1 illustrates that the representation of individual signs differs in certain evaluated groups of requirements. However, with the exception of the group of interpersonal skills and attributes and heterogeneous traits connected in group $\mathrm{F}$, the changes of requirement representation in individual groups are statistically insignificant. 


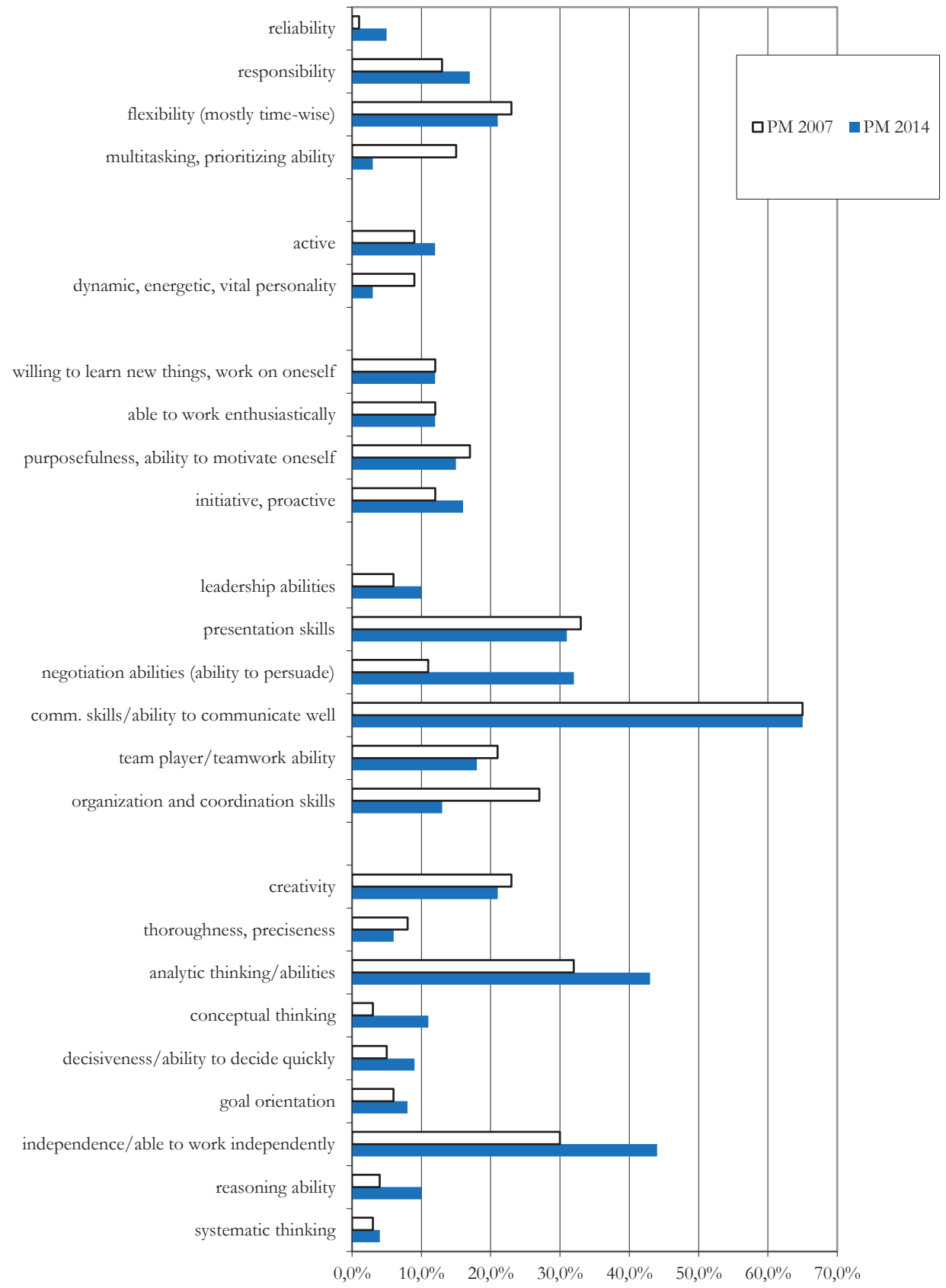

Fig. 1 - Comparison of relative frequency of psychological requirements in 2007 and 2014. Source: Independent research 
Tab. 2 - Two-dimensional analysis for a group of psychological requirements. Source: Independent research

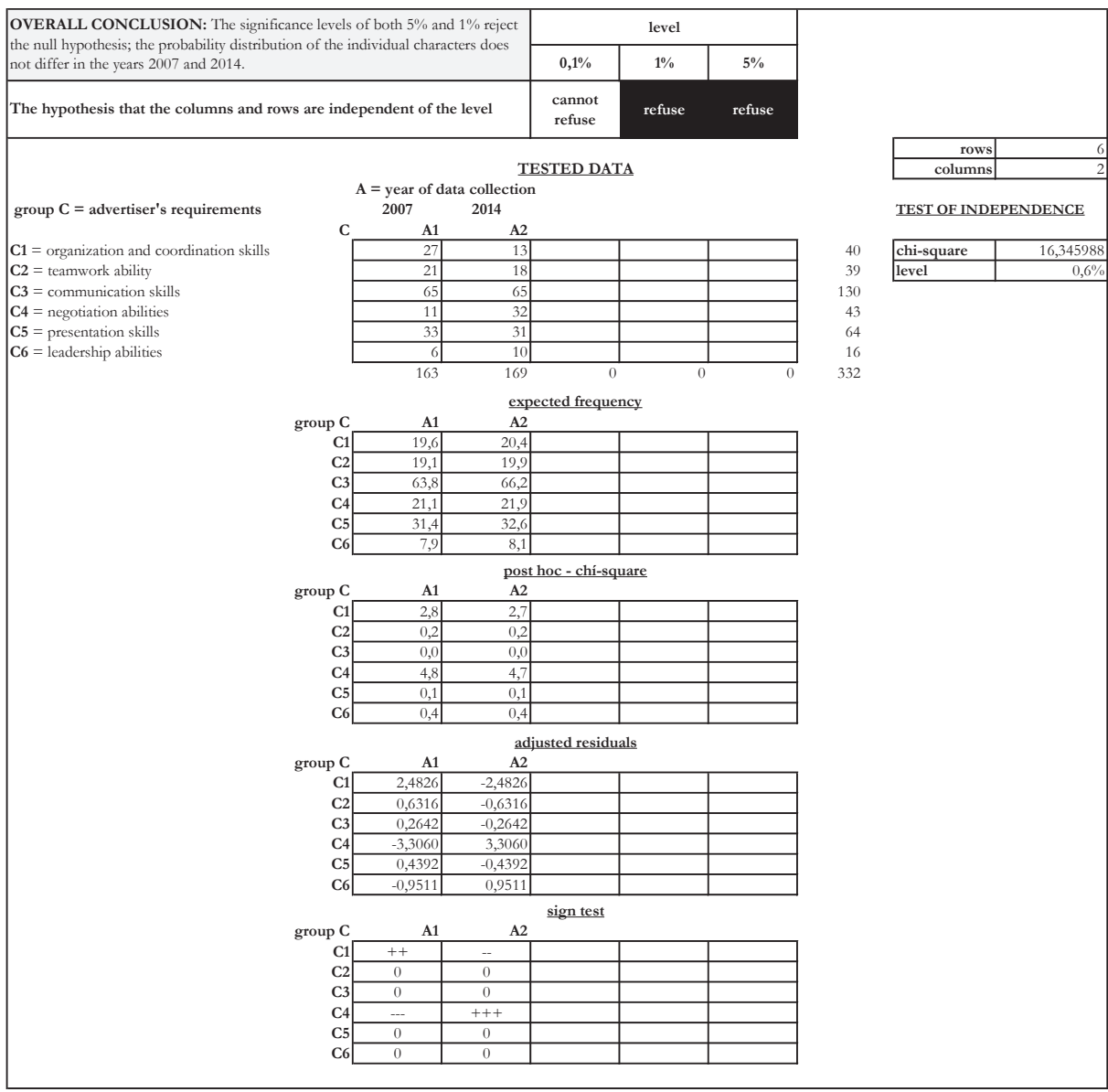

Table 2 demonstrates the statistical verification procedure and presents the results of an independence test.

\section{DISCUSSION FINDINGS AND RECOMMENDATIONS}

The results presented in chapter 4.2 have a direct relation to the goals formulated in chapter 3 . The research project, from which part of the results was presented, began because of this paper's interest in product managers, since they bear a work role, in which the worker is involved in inhouse processes and activities in multiple ways; and this involvement is very high concerning certain internal or external partners. However, in a hierarchically structured organization, they hardly ever have subordinates.

The authors hope that independent empirical research will add to the set of requirements and demands on product managers. Literary research only yielded relatively general delimitations of 
competencies, or partial recommendations regarding the desired level of selected competencies, such as the ability to communicate with others and a high level of communication skills (Lehmann \& Winer, 2005). This paper's research in the field of secondary data was more successful, but only in cases when the analysed source explicitly set a product manager on the level of a horizontal team leader, who is responsible for new product development process and is a key decision maker in new product portfolio management. Wroblowská (2011) proved that job descriptions in job advertisements are not a sufficiently valid source of information regarding the tasks and duties of a worker in the advertised role. Therefore, the segments of the advertisements, which directly mentioned leading a product team in the job description, were not singled out, because, if not accompanied by information regarding the key indicators of the worker's evaluated performance, even such information can be misleading. On the other side the tendency of product management development stated by Kotler and Keller (2013) entitles this study to compare these results with studies, which researched personality prerequisite and behavioural skills necessary for successful product innovation. As was stated in chapter 2, experts agree on the growing significance of cross-functional teams, which are often entrusted with innovation in many fields (Kotler and Keller, 2012; Kumar, 2008; Tomek and Vávrová, 2011). It is therefore necessary to discuss out results in relation to this reality. The authors believe that business practice does not seek people for insignificant tasks, but instead looks for and selects those, who already have skills or prerequisites to grow into key roles, such as product owner.

The following part of the discussion will first focus on confirming the research assumption and then compare the findings with published studies.

Disregarding requirements on specialized knowledge and skills of a knowledge worker, it is possible to look to Truneček's inspiring opinion (2003), which requires knowledge workers to be primarily able to think in context, able to learn continually, independent, emotionally intelligent and personally flexible. The ability to work independently (independence) is a characteristic, which, according to Truneček (2004), is a prerequisite for the performance of a knowledge worker; a member of a specific group of elite professions, so called Golden Collars. This research showed that independence, with a frequency of $44 \%$, is one of the most frequent requirements of a candidate for the job of product manager; a possible interpretation for that is that this characteristic includes the product manager in the elite group of knowledge workers mentioned by Truneček. Mládková (2008) in her formulation of so called Golden Skills did not leave out independence either, and she accompanied it with a problem-solving ability and creativity, which is indispensable especially in workers who base their work on their tacit knowledge. A look at chart one will mistakenly show that a problem-solving competency did not appear in the requirements. However, it is obvious that the advertisers required the candidate to have qualities, which condition this competency, such as reasoning ability or analytic thinking, which in 2014 was the third most frequent requirement on personality dispositions, attribute and behavioural competencies of candidates.

With regard to the role of innovation in the global competition, a more frequent requirement of creativity in the advertisements was expected. However, this paper's finding cannot be classified as not confirming the assumptions. Creativity is a multi-component competency and some of its components overlap attributes or dispositions which are advertised separately. Reason- 
ing ability and systematic thinking comprise the schematic component of creativity, with other components, according to Hlavsa (1985 in Hroník, 2007) being the imaginative and heuristic component, where the latter includes creative thinking.

The discussion of the second assumption will, because of this paper's aim, limit itself to the statement that some differences were noted. The statistically significant shift was presented in Table 2. The "ability to communicate well" was confirmed on the top position in the group of interpersonal skills. A fact worthy of attention is the increase in number of advertisements requiring "the ability to persuade", which is very tightly connected to the competency to "communicate efficiently". Multitasking, which is understood as the ability to conduct several cognitive activities simultaneously, has been much less frequent in advertisements in comparison to 2007. It is not interpreted as making concessions from previous requirements. The authors believe that the advertisers were more careful in confronting the candidates during recruitment with requirements indicating that the work role will be exhausting and can lead to burnout syndrome. Continuing to the Big Five model, it is necessary to state that these results do not give enough material to discuss. Despite that, it is indubitably useful to subject candidates to assessment, which will uncover the levels of conscientiousness, extraversion, openness towards new and ambiguous things and the remaining two personality characteristics. The fact that in 2014 , the requirement for responsibility, which has conscientiousness, part of the Big Five, as its source trait, exceeded the $3 \%$ limit, is proof that advertisers have been looking for more mature individuals than they did in the period of economic boom, before the onset of the crisis. To add to that, there was a significant increase of demand for hard skills, see Wroblowská and Ruda (2015).

McNally et al. (2007) used the qualitative research case study method to study whether the cause of difference in efficiency of product strategy implementation lies in disposition factors of managers involved in new product portfolio management (NPPM). The research was conducted in organizations from different fields on the B2B market in USA, which were connected by the fact that they saw new products as the key to the future of their company. The authors focused on manager dispositions that are relevant in new product portfolio management. Amongst other things they found the ability to break down complex problems into components and evaluate each component's impact, it means the analytic cognitive style plays a role in balancing project innovativeness and release date while also ensuring resource availability. Managers are recommended to consider the personality traits of managers involved in NPPM decisions to ensure thorough consideration of all dimensions: change resistance, ambiguity tolerance, analytic cognitive style and leadership style. The above stated conclusion, which is related to the topic of this paper and underlines the importance of the competency "problem-solving ability", fully corresponds to its victory in the overview of TOP competencies, which was acquired from a survey conducted by the North American Human Resource Management Association in collaboration with the National Association of Manufacturing. The requirement for "problem-solving ability" reached $78 \%$ in its relative frequency and it was followed by the ability to use information technologies and teamwork ability (Casner-Lotto and Barrington, 2006 in Noe et al., 2010).

Magni et al. (2013) studied the new product development (NPD) projects, when the geographic dispersion was increasingly becoming a reality for NPD teams. Their article took into account both the structural and psychological facets of dispersion. The authors found that limiting real- 
time interactions made it difficult to have timely access to other team members' knowledge. At the same time, the ability of business organizations to cope with transnational product innovation depends on their ability to transfer and use the tacit knowledge of markets (Venkatraman \& Subramanian, 2001). Another thing that determines the success of an international product strategy is the experience of individuals and the structure of their personalities. Attributes needed for leadership, that is initiative and social perceptiveness, were evaluated by Manolova and Brush (2002 in Hollensen, 2011) as key, together with a proactive approach to seeking market opportunities, innovativeness, and a resolve to bear risks. It is also necessary to add that in order to handle the career opportunity to work in a product team in the beginning of the 21 st century successfully, Crawford a Di Benedetto (2000) recommended not only expertise and experience, together with willingness to take risks and be devoted to one's goal, but also the ability to develop creativity and manage chaos.

A practical use of such a structured knowledge base is a set of recommendations for recruitment and selection strategy, which is left for discussion to the scientific public. Above all, it is recommended to fully use the possibilities of e-recruitment and to combine several selection methods in the recruitment process. Knowledge workers are interested both in the job description, and in its relations to other functional posts in the organization and possibilities of further development; a profile of the work role of product manager should therefore be detailed, whether the selection is to be undertaken from internal or external sources, which disadvantages classical ways of advertisement. In order to capture the attention of the best, who are possibly not even looking for a job actively, it is appropriate to accompany the advertisement with using podcasts and boosting the job offer's visibility on social networks of professionals, primarily LinkedIn.

In the recruitment process the recommendation is not to make concessions on the generally applicable rule of no discrimination and to consistently verify candidates' qualification, applying both past-oriented methods and methods capturing the current state, and combining the faceto-face method with written contact. To be specific, it is suitable to accompany a personal anamnesis, which starts any selection, by an interview, if there are any unclear points in the career.

If the candidate's problem-solving ability is to be verified, it will be necessary to use selective Cognitive Ability Tests. It is recommended to test analytic quantitative ability, analytic verbal comprehension and reasoning ability. Another recommendation is to replace personality tests using candidates' self-assessment with an online psychodiagnostics system, whether that is online testing using the Assessment Centre method or applied in a selection process, which does not include the Assessment Centre method. This recommendation relates not only to the aspect of cost, but also goal achievement. Projective techniques, if they are set correctly to allow mapping emotional and temper characteristics, serve to identify possible barriers against good performance in a hectic and stressful environment. Finally, a well-built value questionnaire can be used even for motivator identification, if it leads to the same quality of output as a brilliantly led structured interview. After all, because of its costliness, it is suitable to use the interview primarily as a complementary method of verifying the level of competencies and personal integrity of a candidate.

At least the companies that see their employees as a source of future values, because their intellectual potential can generate innovation, which distinguish the products and services of a 
certain organization from its competition and makes the offer unique, should accept the costly complex method Assessment Centre, replaced or accompanied by a behavioural interview. These two methods determine the candidates' self-marketing and uncover to what extent the candidates' successes and ambitions are based on their personal qualities.

\section{CONCLUSION}

The research in the field of secondary data yielded a knowledge base, which was used in the discussion, connecting both already formulated opinions of experts and available empirical findings with this study's results.

The research, which applied the content analysis method on texts of advertisements for the job of product manager, confirmed that workers in roles of product managers rate amongst knowledge workers, with independence and analytic thinking ability being the most frequent requirements of product managers both in 2007, the time of economic boom, and in 2014, when the Czech market once again met economic recovery, which allowed for data comparison. The comparison detected some differences, but statistical verification confirmed a shift of requirements in the interpersonal competency group. The requirement "able to communicate well" had the same, and the highest, frequency in this group, that being $65 \%$, but other requirements had shifts in frequency. The biggest difference in frequency was detected in the ability to negotiate.

Experts estimate that the work role of product manager will keep shifting from the role of individual coordinator towards the role of leader of cross-functional teams, and it can be expected that the psychological demands of this work will stay a significant factor, which makes seeking the most suitable candidate problematic. With regard to that, recommendations for the realization of recruitment process and selection of product managers were formulated and offered for discussion.

Acknowledgement:

The research was conducted in the framework of a UK FTVS Praha research goal SVV - 2015 - 260236 P.

\section{References}

1. Armstrong, M. (2006). A Handbook of Human Resource Management Practice. London: Kogan Page.

2. Berelson, B. (1952). Content Analysis in Communication Research. Glencoe III.: The Free Press.

3. Crawford, M. C., \& Di Benedetto, A. C. (2000). New Products Management. New York: McGraw-Hill.

4. Crawford, M. C., \& Di Benedetto, A. C. (2011). New Products Management. New York: McGraw-Hill/Irwin.

5. Drucker, P. F. (2000). Výzyy managementu pro 21. století. Praha: Management Press.

6. Edvinsson, L., \& Malone, M. S. (1997). Intellectual Capital: Realizing your company's true value by finding its bidden brain power. New York: Harper Business.

7. Franková, E. (2011). Kreativita a inovace v organizaci. Praha: Grada Publishing. 
8. Gorchels, L. (2011). The Product Manager's Handbook. New York: McGraw-Hill.

9. Hollensen, S. (2011). Global Marketing: A Decision-oriented Approach. London: Prentice Hall.

10. Kotler, P., \& Keller, L. K. (2007). Marketing management. Praha: Grada Publishing.

11. Kotler, P., \& Keller, L. K. (2012). Marketing management. New Jersey: Prentice Hall.

12. Kotler, P., \& Keller, L. K. (2013). Marketing management. Praha: Grada Publishing.

13. Kumar, N. (2008). Marketing jako strategie vedouci k úspèchu. Praha: Grada Publishing.

14. Landau, E. (1971). Psychologie der Kreativität. Münich: Ernst. Reinhardt Verlag.

15. Lehmann, D. R., \& Winer, R. S. (2002). Product management. New York: McGraw-Hill

16. Lehmann, D. R., \& Winer, R. S. (2005). Product management. New York: McGraw-Hill.

17. Magni, M., Maruping, L. M., Hoegl, M., \& Proserpio, L. (2013). Managing the unexpected across space: Improvisation, dispersion, and performance in NPD teams. Journal of Product Innovation Management, 30 (5), 1009-1026. doi:10.1111/jpim.12043

18. McDonald, M., \& Wilson, H. (2012) Marketingový plán: př́prava a úspěšná realizace. Brno: BizBooks.

19. McNally, R. C., Durmuşoğlu, S. S., \& Calantone, R. J. (2007). New product portfolio management decisions: Antecedents and consequences. Journal of Product Innovation Management, 30 (2), 245-261. doi:10.1111/j.1540-5885.2012.00997.x

20. Miovský, M. (2006). Kvalitativníprǐstup a metody psychologickébo výžkumu. Praha: Grada Publishing.

21. Mládková, L. (2004). Management žnalostí v praxi. Praha: Professional Publishing.

22. Mládková, L. (2008). Management żnalostnich pracovníkư. Praha: C. H. Beck.

23. Nakonečný, M. (1998). Základy psychologie. Praha: Academia Praha.

24. Noe, R. A., Hollenbeck, J. R., Gerhart, B., \& Wright, P. M. (2010). Human Resource Management: Gaining a Competitive Advantage. New York: McGraw-Hill Irwin.

25. Řezanková, H. (2007). Analýza dat z dotaznikeovích šetrení. Praha: Professional Publishing.

26. Schultz, T. W. (1981). Investing in People: The economics of population quality. Berkley (CA): University of California Press.

27. Subramaniam, M., \& Youndt, M. A. (2005). The Influence of Intellectual Capital on the Types of Innovative Capabilities. Academy of Management Journal, 48 (3), 450-463. http:// dx.doi. org/10.5465/AMJ.2005.17407911

28. Sveiby, K.-E. (1997). The New organizational wealth: Management \& Measuring Knowledge-Based Assets. San Francisco: Berrett-Koehler Publishers.

29. Štikař, J., Rymeš, M., Riegel, K., \& Hoskovec, J. (2003). Psychologie ve svèté práce. Praha: Karolinum.

30. Tomek, G., \& Vávrová, V. (2009). Jak avýsit konkurenčni schopnost firmy. Praha: C. H. Beck. 
31. Tomek, G., \& Vávrová, V. (2011). Marketing od myšlenky k realizaci. Praha: Professional Publishing.

32. Truneček, J. (2003). Znalostni podnik ve znalostní společnosti. Praha: Professional Publishing.

33. Truneček, J. (2004). Management żnalostí. Praha: C. H. Beck.

34. Urbancová, H. (2013). Kontinuita znalostí: jak uchovat znalosti klícových pracovník ů v organizaci. Praha: Adart.

35. Venkatraman, N., \& Subramanian, M. (2001). Determinants of transnational new product development capability: Testing the influence of transfering and deploying tacit overseas knowledge. Strategic Management Journal, 22 (4), 359-378. doi:10.1002/smj.163.abs

36. Wroblowská, Z. (2011). Lidský faktor v produktovém managementu. Disertační práce, Vysoká škola báňská - Technická universita Ostrava, Ostrava.

37. Wroblowská, Z. (2012). Identifikace role produktového manažera a vytvoření standardní typové pozice Produktový manažer. Trendy ekonomiky a managementu, 6 (11), 98-108.

38. Wroblowská Z., \& Ruda, T. (2015) Identifikace požadavků kladených na produktové manažery v procesu náboru. Marketing Science \& Inspirations,10 (1), 9-21.

\section{Contact information}

RNDr. Zuzana Wroblowská, Ph.D.

Banking Institute

College of Banking

Nárožni 2600/9, Praha 5

Czech Republic

email:zwroblowska@bivs.cz.

Mgr. Tomáš Ruda

Charles University in Prague

Faculty of Physical Education and Sport

Department of Sport Management

José Martíbo 31, 16252 Praha 6

Czech Republic

email:ruda@rudito.cz. 